\title{
Influence of stem cuttings, spacing, group planting, light, irrigation and harvesting period on yield in Plectranthus vettiveroides (K.C. Jacob) N. P. Singh \& B. D. Sharma
}

\author{
P.M. Safeer ${ }^{1}$, S. Sreekumar ${ }^{2}$, P. N. Krishnan ${ }^{3}$, C. K. Biju ${ }^{4}$ and G. Seeja ${ }^{5}$ \\ ${ }^{1,2,3,4}$ Saraswathy Thangavelu Centre, Jawaharlal Nehru Tropical Botanic Garden and Research Institute, \\ Puthenthope, Thiruvananthapuram-695586, Kerala \\ ${ }^{5}$ Department of Plant Breeding \& Genetics, College of Agriculture, Vellayani, Thiruvananthapuram,
}

\begin{abstract}
Field experiments were conducted during 2010-11, near coastal area at Jawaharlal Nehru Tropical Botanic Garden and Research Institute (JNTBGRI), Puthenthope, Thiruvananthapuram for the development of agrotechnology package in Plectranthus vettiveroides. For propagation, the positional effect and size of stem cuttings on survival rate and sprouting under open and 50\% shade net conditions were tested. Influence of stem cuttings from shoot tip to basal portion, individual and group planting per pit, spacing, light intensity, irrigation schedule and harvesting period on growth performance and yield were also tested. The results revealed that four shoot tip cuttings with 1-6 nodes ( 15 cm length) planted per pit at a spacing of $35 \mathrm{~cm} \times 35 \mathrm{~cm}$ under light intensity range of 3000-6000 lux and irrigated daily twice during morning and evening hours showed optimum growth performance and yield. The plants harvested after 70 days of planting yielded maximum shoot and root biomass and oil per unit area basis.
\end{abstract}

Keywords: Plectranthus vettiveroides, spacing, stem, planting, irrigation, harvest, light, shoot tip, yield

\section{Introduction}

Offering suitable agrotechniques and promoting the cultivation of economically important crops especially belonging to the category of endemic and extinct taxa in its original habitat as well as adaptable new localities are the best option for its conservation and sustainable utilization. Plectranthus vettiveroides (K.C. Jacob) N. P. Singh \& B. D. Sharma (Syn. Coleus vettiveroides K.C. Jacob) locally known as 'Iruveli' in Malayalam, 'Vettiver' or 'Kuruver' in Tamil belongs to the family Lamiaceae is a succulent herb with strong aromatic fibrous roots. It is an endemic to south Indian medicinal plant which has now extinct in the wild and available only very shrinking population under cultivation in Kollidam, Cuddalore district, Tamil Nadu. Here the plant has been cultivated by a few farmers for fulfilling their religious customs and devotion. As part of it the villagers' are reluctant to give out the plants for cultivating outside the village. There are many reasons prevailing to its extinction from the wild. They include non flowering/lack of seed sets, grow well only in sandy soil with rich moisture and under open sunlight. Moreover though it is a short duration and high value crop, its cultivation is not much economic to the farmers mainly due to difficulty in harvesting the thin and fibrous roots from soil. In early $20^{\text {th }}$ century the plant was cultivated on large scale in North Arcot, Coimbatore, Madurai, Thanjavur, Tirunelveli and Chengalpattu districts in Tamil Nadu and Palakkad district in Kerala. It was also cultivated in some localities of Karnataka but currently cultivated only in Kollidam. Traditionally it is used for curing eye burning, head ache and fever. The root derived essential oil has bitterness with antibacterial, deodorant and cooling action [1]. This oil is preferred by physicians especially in the Western countries as a sanitation agent for hand wash [2]. In some regions of Tamil Nadu, Karnataka and Andhra Pradesh the root has been used for worshipping the temple deities [3] and also for making several household products such as bathing soap, agarbatti, hair oil etc [4]. About 40 herbal drugs currently available in the market contain $P$. vettiveroides as single or as an ingredient in compound drugs [5]. But due to the scarcity of raw material the drug manufactures are forced to use adulterants. At present, the cost of roots per plant in the local market ranges between Rs. 50 to 150 depends on its availability and yield per plant. The demand for its root is increasing, but commercial scale cultivation has not being practiced and popularized mainly due to the lack of standardized agro-technological package of practices, scarcity of planting materials as well as unawareness about this high value crop among the farming community. In the light of these, the National Medicinal Plants Board (NMPB), Government of India has recognized the plant as a top priority one for conservation and large scale cultivation. To fulfill the forgoing task the authors have been engaged in developing agro techniques and as part of it field experiments were conducted to find out the influence of stem cuttings, spacing, group planting, light, irrigation and harvesting period on growth performance and yield. 


\section{Material and Methods}

Field experiments were conducted at Saraswathy Thangavelu Centre of Jawaharlal Nehru Tropical Botanic Garden and Research Institute (JNTBGRI), Puthenthope, Thiruvananthapuram situated $100 \mathrm{~m}$ to $150 \mathrm{~m}$ away from the coastal belt at $8^{\circ} 34^{\prime} 51^{\prime \prime} \mathrm{N}$ latitude and $76^{\circ} 50^{\prime} 3^{\prime \prime} \mathrm{E}$ longitude in all seasons of the year 2010 and 2011. The soil of the experimental site was sandy in texture with $\mathrm{pH} 6.25$, organic carbon $0.24 \%$, phosphorous $19 \mathrm{ppm}$ and potassium $25 \mathrm{ppm}$. To find out positional effect and size of stem cuttings on propagation, nodal cuttings with or without shoot tip of various sizes isolated from shoot tip to basal portion of shoots were planted under open sunlight (6550-12000 lux) and 50\% shade net. The percentage of survival and length of sprouts emanated from the axillary buds in nodal cuttings were recorded. To determine positional effect of stem cuttings on growth and yield $10-15 \mathrm{~cm}$ shoot tip and basal stem cuttings were planted under open sunlight and recorded the growth performance and yield parameters after 70 days of planting. To determine the optimum spacing of planting shoot tip cuttings $(10 \mathrm{~cm}$ to $15 \mathrm{~cm})$ were planted at a spacing of $35 \mathrm{~cm} \times 35 \mathrm{~cm}, 45 \mathrm{~cm} \times 45 \mathrm{~cm}, 50 \mathrm{~cm}$ $\times 50 \mathrm{~cm}, 55 \mathrm{~cm} \times 55 \mathrm{~cm}$ and $60 \mathrm{~cm} \times 60 \mathrm{~cm}$. To find out the influence of individual and group planting shoot tip cuttings $(10 \mathrm{~cm}$ to $15 \mathrm{~cm})$ were planted as single, two, three, four and five cutting(s) per pit. The growth performance was daily evaluated upto 70 days of planting. To find out the influence of light intensity on growth and biomass yield shoot tip cuttings were planted in the field and exposed under different light intensity. Shade net with different grade such as $35 \%, 50 \%$ and $75 \%$ were used to provide different light intensity. Shade net was layered one meter above the ground level in such a way that the shade net having $1.5 \mathrm{~m}$ width layered over the soil bed and allowed to hang $50 \mathrm{~cm}$ on all sides of the soil bed. Such a design was used to exclude any direct illumination and to obviate any microclimate alterations due to the presence of the shade net. Light intensity was measured during morning, noon and evening hours using photometer (Li-cor LI-185B) during the cultivation period. The mean range of light intensity under open sunlight, $35 \%, 50 \%$ and $75 \%$ shade net condition was $6550-12000$ lux, 4000-10000 lux, 3000-6000 lux and 1600-5000 lux respectively. To study the influence of irrigation schedule shoot tip cuttings were planted in 10 inch diameter earthen pots and watered once in a day (morning), twice in a day (morning and evening), thrice in a day (morning, noon and evening), once in 2 days (morning) and once in 3 days (morning) and recorded the growth and root yield. In order to determine the best harvesting period the plants were harvested since after 40 days of planting at 10 day intervals upto 80 days and recorded the root yield. In all experiments land was prepared as per the standardized techniques reported by the authors [4] and plants were kept under open sunlight. All other parameters were kept as constant except the parameters that were treated.

All experiments were laid out in Randomized Block Design (RBD) and replicated thrice. Observations on plant height $(\mathrm{cm})$, leaves/plant, leaf area $\left(\mathrm{m}^{2}\right)$, branches/plant, shoot biomass (tonnes/ha), primary roots/plant, root length $(\mathrm{cm})$ and root biomass (tonnes/ha) were recorded at the time of harvesting. To determine the essential oil yield the harvested fresh roots were distilled in Clevenger apparatus for 4 hours. The essential oil yield per unit area (litres/ha) was determined by multiplying the essential oil yield per gram dry weight into total biomass yield. The data were statistically analyzed using analysis of variance (ANOVA) and critical difference (CD) at $5 \%$ level for comparing the treatment means.

\section{Results and Discussion}

The stem cuttings having different size and number of nodes isolated from various positions i.e., from shoot tip to basal portion of shoot, planted under open sunlight (6550-12000 lux) showed that stem cuttings having single node $(3.0 \mathrm{~cm})$ derived from shoot tip to below ninth node did not survived and they were dried off within 3-5 days of planting. In presence of high light intensity the micro cuttings could not survive. The stem cuttings having more than $4.0 \mathrm{~cm}$ length and minimum two nodes only survived and produced new sprouts. The stem cuttings with more than two nodes with or without shoot tip tested, maximum survival rate obtained from basal cuttings but maximum number of sprouting with comparatively good percentage of survival rate as well as sprout length observed in shoot tip with first to sixth node having $\sim 15 \mathrm{~cm}$ length (Table 1). The tissues at basal portion are more rigid, thicker and contain reserve carbohydrates for short term nourishing to evoke the axillary buds when compared to top cuttings which consist of tender tissues that can not withstand even slight changes in environmental condition. The basal stem cuttings also have more deposition of auxins which would promote faster root initiation [6]. The stem cuttings with single node $(3.0 \mathrm{~cm}$ length) planted under $50 \%$ shade net were survived and produced sprouts (Table 2). The stem cuttings with or without shoot tip having more than one node randomly selected and tested indicate that although survival rate was significantly high under shade net condition more number of healthy sprouts and better growth performance observed under open sunlight. Maximum number of sprouts in stem cuttings isolated from shoot tip portion might be due to the actively growing tissues in this part.

Significant differences in growth performance and yield were recorded when shoot tip and basal stem cuttings were compared as source of planting material except for number of primary roots, fresh root weight and oil yield (Table 3). The over all growth performance parameters indicated that shoot tip cuttings were 
significantly superior to basal stem cuttings in Plectranthus vettiveroides. Better growth performance and biomass yield from shoot tip cuttings might be due to sprouting ability of the apical meristem and retention of auxins in macro cuttings, which induce rooting [7,8,9]. The slower activity or responses in older tissues lead to higher mortality rate in bottom position as compared to top cuttings [10]. According to Darus the rooting percentage of cuttings taken from older tissues decreased sharply probably due to anatomical barriers such as thickening of sclerenchymatous cells, which becomes a barrier for root initiation [11].

Planting to an optimum plant density at proper spacing is of prime importance to improve productivity in many crops $[9,12]$. Among the spacing treatments tried, all growth parameters except number of branches per plant were showed linear increase with planting space widening to an optimum level of $50 \mathrm{~cm} \times 50 \mathrm{~cm}$ and further increase in space widening decreased growth performance. On Brassica and Zea similar observations were reported $[13,14,15]$. In the present study maximum number of branches per plant was observed when planted at a spacing of $55 \mathrm{~cm} \times 55 \mathrm{~cm}$ but plant height showed marked decline. This may be due to enhanced lateral growth with wider spacing facilitate high axillary shoot proliferation and canopy coverage $[9,16,17]$. The shoot biomass, root biomass and oil yield per hectare area revealed that maximum shoot biomass $(15.10$ tonnes/ha), root biomass (1.83 tonnes/ha) and oil yield obtained when plants were cultivated at a spacing of 35 $\mathrm{cm} \times 35 \mathrm{~cm}$ (Table 4). This was significantly different from the rest of the spacing treatments $(45 \mathrm{~cm} \times 45 \mathrm{~cm}$, $50 \mathrm{~cm} \times 50 \mathrm{~cm}, 55 \mathrm{~cm} \times 55 \mathrm{~cm}$ and $60 \mathrm{~cm} \times 60 \mathrm{~cm}$ ), which showed linear decrease in consonance with planting space widening. This might be due to increasing the number of plants per unit area and similar findings were reported earlier in several crops [18,19]. Based on the above results for economic production, $35 \mathrm{~cm} \times 35 \mathrm{~cm}$ spacing can be recommended.

Individual and group planting showed significant difference in growth parameters except plant height, number of leaves, leaf area and root length. All growth parameters showed at higher level when planted single cutting per pit and increasing the number of cuttings per pit decreased the productivity of individual plants. This may be due to increase in individual competition between plants above and below ground for space, nutrient, moisture, sunlight and other growth enhancing attributes leading to maximum linear and vertical growth of plant. Though there was no significant difference in plant height, number of leaves per plant, leaf area and root length, the difference were significant when the productivity and yield were calculated on area basis. In this case maximum shoot weight (10.23 t/ha), root weight (1.42 t/ha) and oil yield (6.65 lit./ha) was obtained with four cuttings/pit (Table 5 and Fig 1). This might be due to optimum plant density per unit area for better growth [20]. Based on these findings for the enhanced yield four cuttings per pit can be recommended, since this treatment was significantly superior to the other treatments tried.

Influence of light intensity showed that maximum growth and biomass were recorded in plants cultivated under light intensity of 3000-6000 lux. Number of leaves, leaf area, fresh shoot weight ( $\mathrm{g} / \mathrm{plant}$ ), root length/plant $(\mathrm{cm})$, fresh root weight $(\mathrm{g} / \mathrm{plant})$, oil yield /plant $(\mathrm{ml})$ were highly significant over other light intensities tested. Number of branches / plant and number of primary roots/ plant were also recorded maximum under 3000-6000 lux, while plant height increased in accordance with increasing light intensity and recorded maximum under 6550-12000 lux (Table 6). Results revealed that plants grown under 50\% shade net with average light intensity of 3000-6000 lux was the best for maximum growth and biomass yield (Fig 2). In general plant growth rate will increase in accordance with increasing light intensity to a certain level and above the critical level growth rate will be decreased. Both deficient and excessive light intensities than optimum level may be injurious to plants and it will affect plant growth, development and yield. Plant responses to light intensities differ even between species for its growth and development and have been well studied [21,22].

Different irrigation schedule tried maximum number of leaves/plant, leaf area/plant $\left(\mathrm{m}^{2}\right)$, number of branches/plant, fresh shoot weight/plant (g) and oil yield were recorded when irrigated twice a day (Table 7). This may be due to the reason that it provides optimum water for the plant to absorb in highly porous sandy soil beds. Watering schedule more or less has no effect on plant growth may be due to the reason that water more than the optimum level cannot be utilized by the plant. Root length was recorded maximum when irrigated once in two days may be due to the reason that prolonged watering intervals lead to water deficit in soil and root will show a tendency to elongate for absorbing water from deep soil $[23,24,25]$. Maximum fresh root biomass was recorded when irrigated daily thrice that may be due to the presence of higher amount of water content in the root [26]. Plant height and number of sprout / branches were recorded maximum when irrigated once in a day. Based on the foregoing results irrigation schedule on daily twice can be recommended.

Among the different harvesting period tested optimum root biomass and oil yield was obtained when plants were harvested after 70 days of planting (Table 8). All growth parameters showed a linear increase up to 70 days and after that the shoot and root growth ceased and root length declined due to deterioration of the roots from terminal portion, which will gradually reach to the base in accordance with late harvesting. Harvesting after 70 days of planting was significantly high and superior to that of other treatments for root and oil yield. 


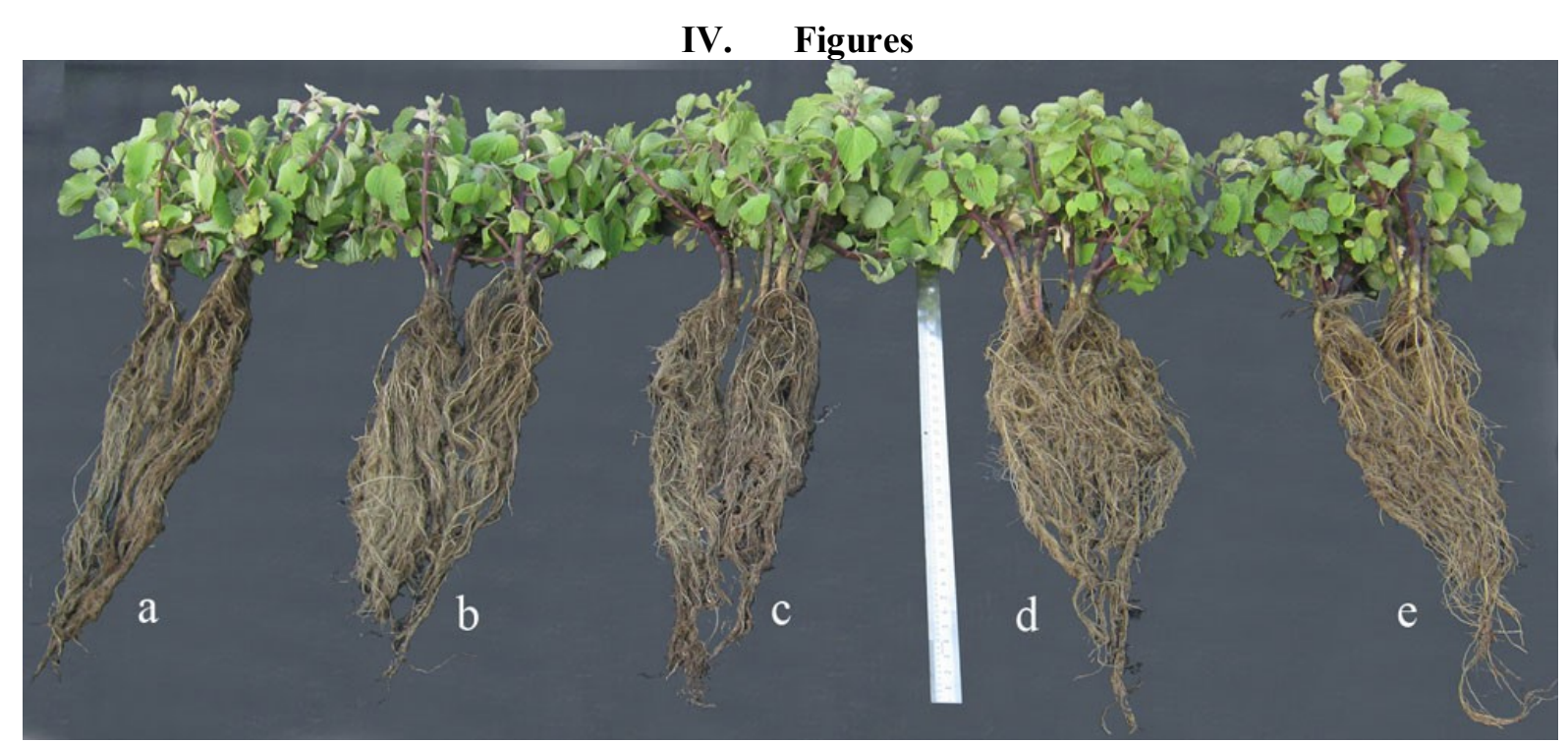

Fig1: Influence of individual and group planting per pit and yield after 70 days of growth in Plectranthus vettiveroides a. single, $\mathrm{b}$. two $\mathrm{c}$. Three, d. Four and e. Five shoot tip cutting(s)/pit.

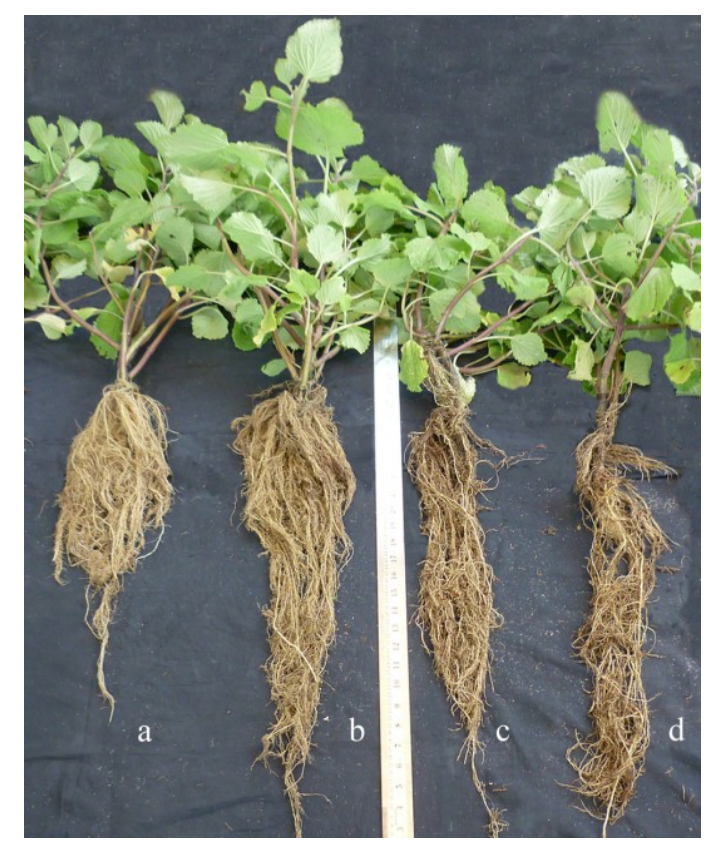

Fig 2: Effect of light intensity (lux) on plant growth a. $1600-5000$, b. 3000-6000, c. 4000-10000, d. $6550-12000$

\section{Tables}

Table 1. Positional effect and size of stem cuttings on survival rate and sprouting under open sunlight in Plectranthus vettiveroides. Observations were recorded after 60 days

\begin{tabular}{|l|c|c|c|c|}
\hline Node Position & Length of stem cutting $(\mathrm{cm})$ & Survival rate (\%) & Sprout / plant & Sprout length(cm) \\
\hline $1^{\text {st }} \& 2^{\text {nd }}$ node* & 4.84 & 28 & $7.3 \pm 0.4$ & $7.1 \pm 0.5$ \\
\hline $1^{\text {st }}$ to $3^{\text {rd }}$ node & 56 & $8 \pm 0.3$ & $12 \pm 2$ \\
\hline $1^{\text {st }}$ to $4^{\text {th }}$ node* & 8.34 & 70 & $10 \pm 0.3$ & $12 \pm 1.5$ \\
\hline $1^{\text {st }}$ to $5^{\text {th }}$ node* & 12.79 & 75 & $10.4 \pm 0.7$ & $15 \pm 2$ \\
\hline $1^{\text {st }}$ to $6^{\text {th }}$ node* & 17.44 & 73 & $2.2 \pm 0.2$ & $8.7 \pm 0.5$ \\
\hline $3^{\text {rd }}$ to $4^{\text {th }}$ node & 22.12 & 72 & $2.2 \pm 0.2$ & $15 \pm 1.5$ \\
\hline $4^{\text {rd }}$ to $6^{\text {th }}$ node & 8.95 & 72 & $1.8 \pm 0.1$ & $8 \pm 2$ \\
\hline $5^{\text {th }}$ to $6^{\text {th }}$ node & 14.78 & 72 & & \\
\hline
\end{tabular}


Influence of stem cuttings, spacing, group planting, light, irrigation and harvesting period on yield

\begin{tabular}{|l|c|c|c|c|}
\hline $5^{\text {th }}$ to $8^{\text {th }}$ node & 19.71 & 75 & $2.2 \pm 0.1$ & $13 \pm 0.5$ \\
\hline $7^{\text {th }}$ to $8^{\text {th }}$ node & 10.38 & 78 & $1.8 \pm 0.1$ & $7 \pm 1$ \\
\hline $7^{\text {th }}$ to $9^{\text {th }}$ node & 15.08 & 72 & $2 \pm 0.1$ & $11 \pm 1$ \\
\hline $6^{\text {th }}$ to $10^{\text {th }}$ node & 21 & 80 & $2.7 \pm 0.2$ & $9.3 \pm 2$ \\
\hline
\end{tabular}

Table 2. Positional effect and size of stem cuttings on survival rate and sprouting under 50\% shade net in Plectranthus vettiveroides. Observations were recorded after 60 days.

\begin{tabular}{|l|c|c|c|c|}
\hline \multicolumn{1}{|c|}{ Node Position } & Length of stem cutting $(\mathrm{cm})$ & Survival rate (\%) & Sprout / plant & Sprout length $(\mathrm{cm})$ \\
\hline $1^{\text {st }}$ node & 2.32 & 17 & $1 \pm 0.1$ & $1 \pm 0.1$ \\
\hline $2^{\text {nd }}$ node & 3.52 & 17 & $1.5 \pm 0.3$ & $5 \pm 0.5$ \\
\hline $3^{\text {rd }}$ node & 4.50 & 58 & $1.8 \pm 0.3$ & $8 \pm 0.3$ \\
\hline $4^{\text {th }}$ node & 5.45 & 64 & $1.6 \pm 0.3$ & $10 \pm 0.6$ \\
\hline $5^{\text {th }}$ node & 5.65 & 72 & $1.5 \pm 0.2$ & $10 \pm 0.7$ \\
\hline $6^{\text {th }}$ node & 5.67 & 75 & $1.2 \pm 0.2$ & $12.5 \pm 1$ \\
\hline $7^{\text {th }}$ node & 5.68 & 81 & $1.2 \pm 0.1$ & $14 \pm 0.4$ \\
\hline $8^{\text {th }}$ node & 5.68 & 81 & $0.9 \pm 0.2$ & $10 \pm 0.7$ \\
\hline $9^{\text {th }}$ node & 5.70 & 81 & $1.1 \pm 0.1$ & $16 \pm 02$ \\
\hline $1^{\text {st }} \& 2^{\text {nd }}$ node* & 4.84 & 28 & $2.2 \pm 0.3$ & $5.5 \pm 2.1$ \\
\hline $3^{\text {rd }}$ to $4^{\text {th }}$ node* & 8.95 & 88 & $2.1 \pm 0.4$ & $12 \pm 2.5$ \\
\hline $5^{\text {th }}$ to $6^{\text {th }}$ node & 10.46 & 75 & $1.9 \pm 0.3$ & $14 \pm 0.9$ \\
\hline $7^{\text {th }}$ to $8^{\text {th }}$ node & 10.96 & 81 & $1.4 \pm 0.1$ & $14 \pm 2$ \\
\hline $1^{\text {st }}$ to $3^{\text {rd }}$ node* & 8.34 & 97 & $7.1 \pm 0.5$ & $12 \pm 3.1$ \\
\hline $4^{\text {th }}$ to $6^{\text {th }}$ node & 14.91 & 97 & $2.9 \pm 0.3$ & $14 \pm 2.5$ \\
\hline $7^{\text {th }}$ to $9^{\text {th }}$ node & 15.66 & 81 & $2.4 \pm 0.3$ & $15 \pm 1$ \\
\hline $9^{\text {th }}$ to $11^{\text {th }}$ node & 15 & $3.1 \pm 0.4$ & $15 \pm 1.6$ \\
\hline
\end{tabular}

*stem cuttings with shoot tip

Table 3. Influence of source of planting material on growth parameters and yield in Plectranthus vettiveroides. Data were recorded after 70 days of planting.

\begin{tabular}{|l|c|c|c|c|c|c|c|c|c|}
\hline $\begin{array}{l}\text { Position of } \\
\text { stem cuttings }\end{array}$ & $\begin{array}{c}\text { Plant } \\
\text { height } \\
(\mathrm{cm})\end{array}$ & $\begin{array}{c}\text { Leaves } \\
\text { / plant }\end{array}$ & $\begin{array}{c}\text { Leaf area/ } \\
\text { plant }\left(\mathrm{m}^{2}\right)\end{array}$ & $\begin{array}{c}\text { Branches/ } \\
\text { plant }\end{array}$ & $\begin{array}{c}\text { Fresh shoot } \\
\text { weight } \\
(\mathrm{t} . / \text { ha })\end{array}$ & $\begin{array}{c}\text { Primary } \\
\text { roots/ } \\
\text { plant }\end{array}$ & $\begin{array}{c}\text { Root } \\
\text { length } \\
(\mathrm{cm})\end{array}$ & $\begin{array}{c}\text { Fresh root } \\
\text { weight } \\
(\mathrm{t} . / \text { ha })\end{array}$ & $\begin{array}{c}\text { Oil } \\
\text { yield } \\
(\text { lit./ ha })\end{array}$ \\
\hline $\begin{array}{l}\text { Shoot tip (1-6 } \\
\text { node) }\end{array}$ & 35.79 & 108.67 & 22.82 & 10.75 & 9.54 & 20.75 & 73.25 & 1.11 & 4.87 \\
\hline $\begin{array}{l}\text { Basal }(7-12 \\
\text { node })\end{array}$ & 23.38 & 77.50 & 16.28 & 7.75 & 4.25 & 12.75 & 66.00 & 0.86 & 3.79 \\
\hline $\mathrm{SE} \pm$ & 0.89 & 6.9 & 1.45 & 0.46 & 1.55 & 3.27 & 0.77 & 0.08 & 0.35 \\
\hline $\mathrm{CD}(p=0.05)$ & 3.1 & 23.98 & 5.04 & 1.6 & 5.37 & $\mathrm{NS}$ & 1.88 & $\mathrm{NS}$ & $\mathrm{NS}$ \\
\hline
\end{tabular}

NS - Not Significant

Table 4. Influence of spacing on growth parameters and yield in Plectranthus vettiveroides. Data were recorded after 70 days of growth period.

\begin{tabular}{|l|l|l|l|l|l|l|l|l|l|}
\hline $\begin{array}{l}\text { Spacing } \\
(\mathrm{cm})\end{array}$ & $\begin{array}{l}\text { Plant } \\
\text { height } \\
(\mathrm{cm})\end{array}$ & $\begin{array}{l}\text { Leaves/ } \\
\text { plant }\end{array}$ & $\begin{array}{l}\text { Leaf area } \\
\text { /plant } \\
\left(\mathrm{m}^{2}\right)\end{array}$ & $\begin{array}{l}\text { Branches/ } \\
\text { plant }\end{array}$ & $\begin{array}{l}\text { Fresh shoot } \\
\text { weight } \\
(\mathrm{t} / \text { ha) }\end{array}$ & $\begin{array}{l}\text { Primary } \\
\text { roots/ } \\
\text { plant }\end{array}$ & $\begin{array}{l}\text { Root } \\
\text { length } \\
(\mathrm{cm})\end{array}$ & $\begin{array}{l}\text { Fresh root } \\
\text { weight } \\
(\mathrm{t} . / \text { ha })\end{array}$ & $\begin{array}{l}\text { Oil } \\
\text { yield } \\
(\text { lit./ ha) }\end{array}$ \\
\hline $35 \times 35$ & 29 & 84.33 & 17.3 & 6.2 & 15.1 & 16.33 & 53.33 & 1.83 & 8.05 \\
\hline $45 \times 45$ & 33.1 & 96 & 20.13 & 7.77 & 11.18 & 20 & 60.86 & 1.36 & 6 \\
\hline $50 \times 50$ & 37.67 & 102.8 & 21.69 & 10.63 & 9.49 & 20 & 60.67 & 1.21 & 5.34 \\
\hline $55 \times 55$ & 23.33 & 81.67 & 17.15 & 16.27 & 6.53 & 16.27 & 54.33 & 0.77 & 3.39 \\
\hline $60 \times 60$ & 21.23 & 53.67 & 11.27 & 8.4 & 3.07 & 11.13 & 34 & 0.37 & 1.63 \\
\hline $\mathrm{SE} \pm$ & 1.53 & 3.48 & 0.71 & 0.46 & 0.25 & 0.83 & 2.67 & 0.03 & 0.14 \\
\hline $\begin{array}{l}\mathrm{CD} \\
(p=0.05)\end{array}$ & 6 & 13.68 & 2.81 & 1.8 & 0.99 & 3.28 & 10.45 & 0.13 & 0.56 \\
\hline
\end{tabular}


Table 5. Influence of individual and group planting on growth parameters and yield in Plectranthus vettiveroides. Data/pit were recorded after 70 days of growth period.

\begin{tabular}{|l|l|l|l|l|l|l|l|l|l|}
\hline $\begin{array}{l}\text { Stem } \\
\text { cutting(s)/ } \\
\text { pit }\end{array}$ & $\begin{array}{l}\text { Plant } \\
\text { height } \\
(\mathrm{cm})\end{array}$ & $\begin{array}{l}\text { No. of } \\
\text { leaves }\end{array}$ & $\begin{array}{l}\text { Leaf area } \\
\left(\mathrm{m}^{2}\right)\end{array}$ & Branches & $\begin{array}{l}\text { Fresh shoot } \\
\text { weight } \\
(\mathrm{t} . / \mathrm{ha})\end{array}$ & $\begin{array}{l}\text { Primary } \\
\text { roots }\end{array}$ & $\begin{array}{l}\text { Root } \\
\text { length } \\
(\mathrm{cm})\end{array}$ & $\begin{array}{l}\text { Fresh root } \\
\text { weight } \\
\text { (t./ha })\end{array}$ & $\begin{array}{l}\text { Oil } \\
\text { yield } \\
(\text { lit./ ha) }\end{array}$ \\
\hline One & 31.92 & 88.17 & 18.52 & 9.75 & 7.50 & 16.33 & 68.08 & 0.79 & 3.63 \\
\hline Two & 27.99 & 94.58 & 19.86 & 11.75 & 7.83 & 18.50 & 69.17 & 0.95 & 4.28 \\
\hline Three & 32.67 & 119.50 & 25.10 & 15.50 & 9.94 & 24.92 & 69.75 & 1.32 & 6.06 \\
\hline Four & 32.88 & 116.75 & 24.52 & 15.67 & 10.23 & 25.58 & 70.17 & 1.42 & 6.65 \\
\hline Five & 30.67 & 110.25 & 23.15 & 16.50 & 9.47 & 26.42 & 67.08 & 1.25 & 5.88 \\
\hline SE \pm & 2.01 & 11.93 & 2.51 & 0.72 & 0.64 & 1.37 & 3.44 & 0.13 & 0.60 \\
\hline $\begin{array}{l}\text { CD } \\
(\mathrm{p}=0.05)\end{array}$ & $\mathrm{NS}$ & $\mathrm{NS}$ & $\mathrm{NS}$ & 2.28 & 2.01 & 4.32 & NS & 0.41 & 1.88 \\
\hline
\end{tabular}

NS - Not Significant

Table 6. Influence of light intensity on growth parameters and yield in Plectranthus vettiveroides. Data were recorded after 70 days of growth period.

\begin{tabular}{|l|l|l|c|c|c|c|c|c|c|}
\hline $\begin{array}{l}\text { Light } \\
\text { intensity } \\
\text { (lux })\end{array}$ & $\begin{array}{l}\text { Plant } \\
\text { height } \\
(\mathrm{cm})\end{array}$ & $\begin{array}{l}\text { Leaves } \\
\text { /plant }\end{array}$ & $\begin{array}{l}\text { Leaf area / } \\
\text { plant }\left(\mathrm{m}^{2}\right)\end{array}$ & $\begin{array}{l}\text { Branches } \\
\text { /plant }\end{array}$ & $\begin{array}{l}\text { Fresh shoot } \\
\text { weight } \\
\text { (t./ ha) }\end{array}$ & $\begin{array}{l}\text { Primary } \\
\text { roots/ } \\
\text { plant }\end{array}$ & $\begin{array}{l}\text { Root } \\
\text { length } \\
(\mathrm{cm})\end{array}$ & $\begin{array}{l}\text { Fresh root } \\
\text { weight } \\
\text { (t./ ha) }\end{array}$ & $\begin{array}{l}\text { Oil yield } \\
(\text { lit./ ha) }\end{array}$ \\
\hline $6550-12000$ & 43.89 & 43.78 & 9.19 & 7.22 & 5.64 & 10.44 & 45.44 & 0.34 & 0.73 \\
\hline $4000-10000$ & 39.56 & 53.22 & 11.18 & 7.44 & 6.13 & 12.67 & 48.00 & 0.60 & 2.15 \\
\hline $3000-6000$ & 35.00 & 74.11 & 15.56 & 8.00 & 7.76 & 13.11 & 60.89 & 1.23 & 11.28 \\
\hline $1600-5000$ & 35.78 & 42.22 & 8.87 & 6.00 & 4.42 & 9.11 & 43.11 & 0.29 & 0.65 \\
\hline S.E \pm & 3.3 & 4.97 & 1.04 & 0.83 & 1.73 & 1.18 & 2.51 & 0.05 & 0.3 \\
\hline C.D $(0.05)$ & NS & 16.24 & 3.4 & NS & 2.75 & NS & 8.2 & 0.14 & 1 \\
\hline
\end{tabular}

NS - Not Significant

Table 7. Influence of irrigation schedule on growth parameters and yield in Plectranthus vettiveroides. Data were recorded after 70 days of growth period.

\begin{tabular}{|l|c|c|c|c|c|c|c|c|c|}
\hline $\begin{array}{l}\text { Irrigation } \\
\text { Schedule }\end{array}$ & $\begin{array}{l}\text { Plant } \\
\text { height } \\
(\mathrm{cm})\end{array}$ & $\begin{array}{l}\text { Leaves } \\
\text { /plant }\end{array}$ & $\begin{array}{l}\text { Leaf area } / \\
\text { plant }\left(\mathrm{m}^{2}\right)\end{array}$ & $\begin{array}{l}\text { Branches } \\
\text { / plant }\end{array}$ & $\begin{array}{l}\text { Fresh shoot } \\
\text { weight (t./ } \\
\text { ha) }\end{array}$ & $\begin{array}{l}\text { Primary } \\
\text { roots/ } \\
\text { plant }\end{array}$ & $\begin{array}{l}\text { Root } \\
\text { length } \\
(\mathrm{cm})\end{array}$ & $\begin{array}{l}\text { Fresh root } \\
\text { weight } \\
\text { (t./ ha) }\end{array}$ & $\begin{array}{l}\text { Oil yield } \\
(\text { lit./ ha) }\end{array}$ \\
\hline Daily once & 37.44 & 61.22 & 12.86 & 13.11 & 6.41 & 19.78 & 67.44 & 0.90 & 9.14 \\
\hline Daily twice & 34.11 & 72.00 & 15.12 & 14.00 & 6.80 & 18.00 & 59.00 & 0.90 & 18.67 \\
\hline Daily thrice & 29.61 & 46.78 & 9.82 & 8.56 & 4.56 & 18.78 & 64.78 & 1.10 & 11.38 \\
\hline $\begin{array}{l}\text { Once in two } \\
\text { days }\end{array}$ & 32.67 & 50.00 & 10.5 & 7.67 & 5.76 & 13.22 & 67.56 & 0.75 & 13.82 \\
\hline $\begin{array}{l}\text { Once in } \\
\text { three days }\end{array}$ & 34.44 & 50.44 & 10.59 & 10.78 & 5.65 & 14.56 & 65.22 & 0.83 & 6.54 \\
\hline S.E \pm & 1.5 & 2.17 & 0.45 & 0.93 & 0.06 & 0.64 & 0.8 & 0.05 & 0.5 \\
\hline C.D (0.05) & 4.72 & 6.85 & 1.43 & 2.92 & 6.45 & 2.02 & 2.51 & 0.13 & 1.5 \\
\hline
\end{tabular}

NS - Not Significant

Table 8. Influence of harvesting period on growth parameters and yield in Plectranthus vettiveroides.

\begin{tabular}{|l|c|c|c|c|c|c|c|c|c|}
\hline $\begin{array}{l}\text { Harvesting } \\
\text { period } \\
(\text { Days })\end{array}$ & $\begin{array}{l}\text { Plant } \\
\text { height } \\
(\mathrm{cm})\end{array}$ & $\begin{array}{l}\text { Leaves } \\
\text { / plant }\end{array}$ & $\begin{array}{l}\text { Leaf } \\
\text { area/ } \\
\text { plant }\left(\mathrm{m}^{2}\right)\end{array}$ & $\begin{array}{l}\text { Branches/ } \\
\text { plant }\end{array}$ & $\begin{array}{l}\text { Fresh } \\
\text { shoot } \\
\text { weight } \\
(\mathrm{t} . / \mathrm{ha})\end{array}$ & $\begin{array}{l}\text { Primary } \\
\text { roots/ } \\
\text { plant }\end{array}$ & $\begin{array}{l}\text { Root } \\
\text { length } \\
(\mathrm{cm})\end{array}$ & $\begin{array}{l}\text { Fresh root } \\
\text { weight } \\
\text { (t./ ha) }\end{array}$ & $\begin{array}{l}\text { Oil yield } \\
\text { (lit./ ha) }\end{array}$ \\
\hline 40 & 19.47 & 16 & 3.36 & 3.4 & 2.39 & 9.83 & 19.43 & 0.33 & 1.45 \\
\hline 50 & 25.33 & 29.77 & 6.25 & 3.73 & 4.12 & 12.93 & 30.67 & 0.5 & 2.35 \\
\hline 60 & 34.73 & 40.87 & 8.58 & 6.3 & 5.67 & 13 & 38.67 & 0.76 & 3.5 \\
\hline 70 & 38 & 60.67 & 12.74 & 8.77 & 6.77 & 13.03 & 47.67 & 0.93 & 4.36 \\
\hline 80 & 35.83 & 50 & 10.5 & 8 & 6.65 & 10.67 & 37 & 0.63 & 2.8 \\
\hline $\mathrm{SE} \pm$ & 1.12 & 1.35 & 0.28 & 0.29 & 0.14 & 0.61 & 1.35 & 0.03 & 0.23 \\
\hline $\begin{array}{l}\mathrm{CD} \\
(p=0.05)\end{array}$ & 4.41 & 5.3 & 1.11 & 1.13 & 0.53 & 2.39 & 5.29 & 0.11 & 0.52 \\
\hline
\end{tabular}




\section{Conclusion}

Based on the results it was recommended to use $\sim 15 \mathrm{~cm}$ long shoot tip cutting having 1-6 node as planting material and planted four cutting per pit at a spacing of $35 \mathrm{~cm} \times 35 \mathrm{~cm}$ with light intensity of 3000-6000 lux and irrigated daily twice during morning and evening and harvesting after 70 days of planting for maximum yield.

\section{Acknowledgements}

We thank National Medicinal Plants Board (NMPB), Government of India for providing financial assistance, Dr. S. Seeni, Former Head of Biotechnology \& Bioinformatics Division, JNTBGRI, Dr. Paneerselvam, Professor and Head and Dr. Manivannan, Assistant Professor, Department of Botany, Anamalai University, Tamil Nadu for their help to collect the planting material from Kollidam and Director, JNTBGRI, Thiruvananthapuram for support and encouragements.

[1] P.K. Warrier, V.P.K. Nambiar and K.C. Raman, Indian Medicinal Plants: A Compendium of 500 species. (Orient Longman, Madras.1995) pp 318-320.

[2] Sunanda Mondal and S.A. Kolhapure, Evaluation of antimicrobial efficacy and safety of pure hands herbal hand sanitizer in hand hygiene and on inanimate objects, The Antiseptic, 101(2), 2004, 55-57.

[3] K.C. Jacob, A new Species of Coleus, Journal of Bombay Natural History Society, 42, 1941, 320-322.

[4] P.M. Safeer, S. Sreekumar, P.N. Krishnan, C.K. Biju and G. Seeja, Influence of soil texture and bed preparation on growth performance in Plectranthus vettiveroides, IOSR-JAVS, 5(3), 2013, 41-45.

[5] A. Saraswathy, K. Amala and Arunmozhi Devi, Coleus vettiveroides K.C. Jacob; Botany and Pharmacognosy, Indian Journal of Traditional Knowledge, 10(4), 2011, 636-642.

[6] Z. Tchoundjeu and R.R.B. Leakey, Vegetative propagation of African mahogany: effects of auxin, node position, leaf area, and cutting length, New Forests, 11, 1996, 125-136.

[7] S. Choummaravong, 'Vegetative propagation of Sentang (Azadirachta excelsa (Jack) Jacobs.) by rooting of cuttings', M.Sc thesis, University Putra Malaysia, Serdang, Selangor, 1998.

[8] Z. Tchoundjeu and R.R.B. Leakey, Vegetative propagation of Lovoa trichiliodes: Effects of provenance, substrate, auxins and leaf area, Journal of Tropical Forest Science, 13(1), 2001, 116-129.

[9] R.M. Kathiresan and I. Gnanavel, Effect of propagation material, N, P and K fertilizers and spacing on Coleus aromaticus (Benth.), Green Farming 3(2), 2010, 122-124.

[10] N.A.S. Aini, V.S. Guanih and P. Ismail, Effect of cutting positions and growth regulators on rooting ability of Gonystylus bancanus, African Journal of Plant Science, 4(8), 2010, 290-295.

[11] A. Darus, Anatomical study on root formation in Acacia mangium stem cutting, Journal of Tropical Forest Science, 2(1), 1989, $20-24$.

[12] V.S. Kubsad, 'Agrotechniques to enhance the Productivity of Ashwagandha (Withania somnifera Dunal) in vertisols of Northern dry Zone of Karnataka'. Ph.D. thesis, University of Agricultural Sciences, Dharwad, 2008.

[13] I.A. Naik and A.J. Gupta, Effect of plant density and integrated nutrient management on growth, yield, quality and economics of Kale (Brassica oleracea var. acephala) in temperate region, Indian Journal of Agricultural Sciences, 80(1), 2010, 80-84.

[14] H.S. Prodhan, P. Khoyumthem, S. Bala and T.K. Basu, Effect of spacing, seed placement and plant density on the yield of baby corn, Annals of Agricultural Research New Series, 31(1\&2), 2010, 52-54.

[15] T.S. Sukanya, H.V. Nanjappa and B.K. Ramachandrappa, Effect of spacing on the growth, development and yield of Baby corn (Zea mays L.), Karnataka Journal of Agricultural Science, 12(1-4), 1999, 10-14.

[16] A.B. Mastiholi and S.M. Hiremath, Influence of spacing and time of harvest on growth attributes and yield of Coleus forskohlii Briq., Journal of Root Crops, 35(2), 2009, 169-174.

[17] A.B. Mastiholi and S.M. Hiremath, Influence of spacing and time of harvest on forskolin content and yield in Coleus forskohlii, Journal of Medicinal and Aromatic Plant Science, 31, 2009, 103-104.

[18] H.P. Maheswarappa, H.V. Nanjappa and M.R. Hegde, Influence of agronomic practices on growth, productivity and quality of Galangal (Kaempferia galanga L.) grown as intercrop in coconut garden, Journal of Plantation Crops, 28(1), 2000, 72-81.

[19] Munnu Singh, Influence of spacing and intercropping on biomass and essential oil yield of Patchouli (Pogostemon cablin (Blanco) Benth.), Journal of Spices and Aromatic Crops, 17(3), 2008, 235-239.

[20] Mirza Hasanuzzamam, M.L. Rahman, T.S. Roy, J.U. Ahmed and A.S.M. Zobaer, Plant characters, yield of late transplanted aman rice as affected by plant spacing and number of seedling per hill, Advances in Biological Research, 3(5\&6), 2009, 201-207.

[21] J.F. De Carvalho Gonçalves, D.C. De Sousa Barreto, Jr. U.M. Dos Santos, A.V. Fernandes, P.D.T. Barbosa Sampaio and M.S. Buckeridge, Growth, photosynthesis and stress indicators in young rosewood plants (Aniba rosaeodora Ducke) under different light intensities, Braz. J. Plant Physiol., 17, 2005, 325-334.

[22] M.A. Hossain and M. Kamaluddin, Effects of lateral shading on growth and morphology of shoots and rooting ability of jackfruit (Artocarpus heterophyllus Lam.) cuttings, Journal of Applied Horticulture, 6(2), 2004, 35-38.

[23] S.Y. Besheit, B.B. Mekki and Maria G. Beshay, Effect of different levels of water supply on sugar beet yield and quality in calcareous soils, J. Agric. Sci. Mansoura Univ., 21(10), 1996, 3429-3436.

[24] S.S. El-Maghraby, M.A. Gomaa, I.F. Rehab and H.M.S. Hassan, Response of sugar beet to some mechanical management practices, irrigation and plant densities, Sugar Tech., 10(3), 2008, 219-226.

[25] A. Abo-Shady Kh., Samia M.M. Hilal, E.El. M. El-Sheref and M.F.M. Ibrahim, Yield and quality of sugar beet crop as affected by irrigation intervals, cultivars and potassium fertilization in north delta, J. Agric. Res. Kafer El-Sheikh Univ., 36(4), 2010, $361-375$.

[26] I.L. Hamma, U. Ibrahim and M. Haruna, Effect of irrigation intervals and NPK application on the growth and yield of carrot (Daucus carota 1.) In Samaru, Kaduna State, Nigeria, Nigerian Journal of Agriculture, Food and Environmen, 8(1), 2012, 59-62. 